\section{Selvhjelp for å slutte med benzodiazepiner}

Bliss Johns

Benzo-wise: A recovery companion

Everything you need to know to cope

successfully with benzodiazepine withdrawal.

2. utg. 200 s, tab. Nichols, IA: Campanile

Publishing, 2010. Pris USD 17

ISBN 978-0-98237592-1

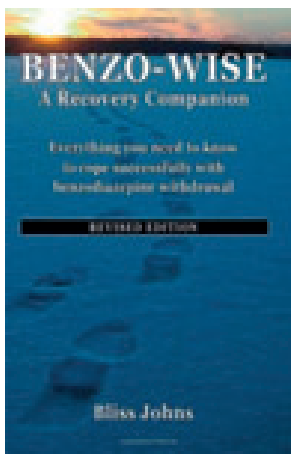

Mer enn 100000

mennesker i Norge

bruker benzo-

diazepiner over

mange år. Noen

bruker mye, noen

bruker mindre. For

noen er dette for-

nuftig hjelp for

angst eller søvn-

problemer, for

andre er det helt

sikkert dumt.

I tillegg til at de antakelig bare får marginal hjelp i forhold til søvn og angst, kan bruken medføre problemer som vansker med hukommelse, nedsatte kognitive funksjoner, nedsatt evne til å føre motorkjøretøy på en sikker måte, og i tillegg være opphav til en god del angstproblemer og søvnløshet.

Noen vil oppleve at det er overraskende lett å trappe ned eller slutte. Andre vil oppleve at det er vanskelig, ja, nesten umulig, å kvitte seg med denne dubiøse hjelpen. Grunnen kan være at seponeringssymptomene er så sterke og så langvarige at selv den mest dedikerte og bestemte kan bli knekt. Seponeringssymptomene kan vedvare utover det som farmakologien kan forklare. Ofte føler man at man får for lite eller ingen hjelp fra den som har foreskrevet medisinene, eller annet helsepersonell. Det kan oppleves både vanskelig og ensomt å gjennomføre en nedtrapping. I en slik situasjon kan kanskje en bok være til hjelp.

\section{Selvhjelpsbok}

Benzo-wise er skrevet av en som brukte klonazepam i mange år. Hun beskriver hvordan hun fikk flere og mer ulike symptomer som hun ikke skjønte hva var, inntil hun kom over The Heather Ashton Manual (1). Hun bestemte seg for å slutte og trappet ned slik Ashton anbefaler. Hun beskriver en smertefull og langvarig prosess, men nettopp hennes ærlige fortelling om opp- og nedturer vil kunne virke empatisk støttende og troverdig for andre som er i en liknende situasjon. Boken har en god del faktakunnskap i form av farmakologi og klinisk kunnskap som er ganske godt skrevet og uten altfor store misforståelser.

Vi får et godt inntrykk av hvordan det er å trappe ned på bruken av benzodiazepiner. Forfatteren brukte selv nesten et halvt år, men forteller levende om hvordan hun strevde med ettervirkninger i nærmere to år etterpå. Hun har mange råd for hvordan man skal styrke seg selv og sin motivasjon når man opplever at det butter imot, noe som ofte skjer. Hun skaper normalitet rundt de mange uspesifikke symptomene som blir møtt med skepsis innen medisinske miljøer. Og hun gir råd til dem som står rundt. Hun er ganske nøktern og usentimental i forhold til egne opplevelser. Boken kan derfor også leses av dem som er skeptisk til slike selvhjelpsbøker. Den er skrevet på et lettfattelig engelsk, uten at det er referert til for mange ting som er spesifikt amerikanske. Et unntak er kapitlet hvor rettslige forføyninger mot leger diskuteres. Det betyr at den kan leses med utbytte av norske pasienter og norske leger.

Boken inneholder en fyldig liste over annen litteratur om emnet og annen selvhjelpslitteratur som kan hjelpe med det grunnleggende problemet og selve nedtrappingen. Nettsider som kan være til nytte, er også nevnt. Det er gode og oversiktlige tabeller over generiske navn og salgsnavn og over noen viktige farmakologiske egenskaper til medikamentene. Det er også noen få eksempler på nedtrappingsregimer. Det er en fyldig ordbok over seponeringssymptomer og til slutt en referanseliste og et fyldig stikkordregister.

I den grad man har pasienter som bør, eller vil slutte med eller trappe ned sin bruk av GABAerge midler, og som kan engelsk på et visst nivå, kan dette oppleves som en god og støttende bok.

\section{Oppsummering}

Det ligger i den amerikanske lege-pasientkulturen at så lenge du bruker legemidlene som foreskrevet, er det uproblematisk (uansett hvor problematisk det er). Dette blir ikke minst reflektert gjennom at man i nyere diagnostiske retningslinjer ønsker å gå lenger i retning av ikke å bruke termer som misbruk og avhengighet om legemiddelbruk som vi i dag ville rubrisere slik (2).
I Amerika vil bøker som Benzo-wise derfor kunne representere et slags konsumentopprør, mens de i Europa og Norge vil kunne anbefales av helsepersonell til pasienter.

Det er også interessant å merke at jo mer personlig fortellende slike historier er, og jo mer uspesifikt man beskriver de psykosomatiske symptomene, desto mer aktiveres min egen «varsler»-reaksjon. Jeg tar meg selv i å tenke: Hvem er denne personen? Benzodiazepiner kan da ikke ha vært årsaken til så mye? Vedkommende må jo ha hatt problemer før! Når du som leser opplever det samme, vil jeg utfordre deg til å spørre tilbake: Spiller svaret på disse spørsmålene noen rolle? Må vi kunne forklare lang tids abstinenssymptomer farmakologisk? Spiller det en rolle om folk har hatt et misbruksproblem før? Er det av betydning for hvordan du forholder deg til dette problemet; om folk har en akse 2-diagnose eller ikke?

Benzo-wise og liknende bøker kan også passe for leger, psykologer eller andre som jobber innen psykisk helsevern eller rus. Skulle du ha et ønske om å hjelpe noen med nedtrapping etter lang tids benzodiazepinbruk og ikke får tilgang til Benzo-wise og tilsvarende bøker, finnes Heather Ashtons veileder gratis tilgjengelig på nett (1). Nyttig er også hjemmesidene til det danske Institut for Rationel Farmakoterapi (3). Det finnes også en norsk bok som dekker området ganske bra for fagfolk, selv om den begynner å bli noen år gammel (4).

\section{Jørgen Bramness}

Senter for rus og avhengighetsforskning Universitetet i Oslo

Litteratur

1. Benzodiazepines: How they work and how to withdraw. www. benzo.org.uk/manual/index.htm (24.1.2011).

2. Bramness JG, Waal H, Mørland J. Unødvendige nyord om avhengighet. Tidsskr Nor Legeforen 2009; 129: 904

3. Benzodaizepiner: Hvordan reduceres forbruget? www.irf.dk/dk/publikationer/

rationel_farmakoterapi/maanedsblad/2007/ benzodiazepiner_hvordan_reduceres_forbru.htm (24.1.2011).

4. Hafseng K. Legemiddelavhengighet: om utvikling av avhengighet og hvordan vi kan møte problemet. Kristiansand: Høyskoleforlaget, 1998. 